\title{
Orostachys japonicus Inhibits Expression of the TLR4, NOD2, iNOS, and COX-2 Genes in LPS-Stimulated Human PMA-Differentiated THP-1 Cells by Inhibiting NF- $\kappa$ B and MAPK Activation
}

\author{
Yeo-Kwang Yoon, Hong-Jung Woo, and Youngchul Kim \\ Department of Internal Medicine, College of Korean Medicine, Kyung Hee University, Seoul 130-872, Republic of Korea \\ Correspondence should be addressed to Youngchul Kim; yckim@khmc.or.kr
}

Received 30 September 2014; Revised 20 January 2015; Accepted 26 January 2015

Academic Editor: Alfredo Vannacci

Copyright (c) 2015 Yeo-Kwang Yoon et al. This is an open access article distributed under the Creative Commons Attribution License, which permits unrestricted use, distribution, and reproduction in any medium, provided the original work is properly cited.

\begin{abstract}
Orostachys japonicus is traditionally used as an inflammatory agent. In this report, we investigated the effects of O. japonicus extract on the expression of genes encoding pathogen-recognition receptors (TLR2, TLR4, NOD1, and NOD2) and proinflammatory factors (iNOS, COX-2, and cytokines) in LPS-stimulated PMA-differentiated THP-1 cells and the NF- $\kappa$ B and MAPK pathways. O. japonicus induced toxicity at high concentrations but had no effect at concentrations lower than $25 \mu \mathrm{g} / \mathrm{mL}$. O. japonicus inhibited LPS-induced TLR4 and NOD2 mRNA levels, suppressed LPS-induced iNOS and COX-2 transcription and translocation, and downregulated LPS-induced proinflammatory cytokine (IL-1 $\beta$, IL-6, IL-8, and TNF- $\alpha$ ) mRNA levels. In addition, $O$. japonicus inhibited LPS-induced NF- $\kappa$ B activation and $\mathrm{I} \kappa \mathrm{B} \alpha$ degradation and suppressed LPS-induced JNK, p38 MAPK, and ERK phosphorylation. Overall, our results demonstrate that the anti-inflammatory effects of O. japonicus are mediated by suppression of NF- $\kappa$ B and MAPK signaling, resulting in reduced TLR4, NOD2, iNOS, and COX-2 expression and inhibition of inflammatory cytokine expression.
\end{abstract}

\section{Introduction}

Orostachys japonicus (O. japonicus) is traditionally used as an inflammatory agent, antifebrile, homeostatic agent, and antidote and anticancer agent [1]. The methanol extract of Orostachys japonicus is thought to contain several different classes of phytochemicals, including triterpenes, sterols, and flavonoids [2]. Inflammation is caused by a variety of factors, including physical and chemical agents, the immune response, and tissue necrosis [3]. However, further studies on O. japonicus are required due to the lack of information on signaling pathways and physiological activity.

Immune cells can recognize pathogen-associated molecules, such as the lipopolysaccharide (LPS) of Gram-negative bacteria, the peptidoglycan (PGN) of Gram-positive bacteria, and mannans of yeast cells through toll-like receptors (TLRs) expressed on the cell surface [4]. Humans have various pathogen-recognition receptors including TLRs, nucleotidebinding oligomerization domain- (NOD-) like receptors
(NLRs), and retinoic acid-inducible gene-1- (RIG-1-) like receptors [5-7]. These receptors transduce signals to activate nuclear factor- $\kappa \mathrm{B}(\mathrm{NF}-\kappa \mathrm{B})$, which subsequently drives the induction of several proinflammatory cytokines and chemokines [8-10]. TLRs are an integral component of the inflammation process. TLR2 and TLR4, along with their ligands, are best characterized in terms of innate responses to bacteria, including Chlamydia. TLR2 is involved in the recognition of a broad range of microbial products, and TLR4 is the signal-transducing receptor for LPS [11]. NOD1 and NOD2 are involved primarily in mediating antibacterial defenses [12]. NOD1 recognizes mainly Gram-negative bacteria, whereas NOD2 recognizes most Gram-positive and Gram-negative bacteria [13].

Inducible nitric oxide synthase (iNOS) is expressed widely in various cell types and is highly expressed in LPSactivated macrophages [14]. Expression of the iNOS gene in macrophages is regulated mainly at the transcriptional level. 
$\mathrm{NF}-\kappa \mathrm{B}$ is a pivotal regulator of important immunoregulatory genes involved in immune and inflammatory responses, including iNOS [15]. Cyclooxygenase-2 (COX-2) is expressed in the presence of many proinflammatory mediators, including LPS, interlukin- $1 \beta$ (IL-1 $\beta$ ), and tumor necrosis factor$\alpha$ (TNF- $\alpha)$, through which high concentrations of prostaglandin $\mathrm{E}_{2}\left(\mathrm{PGE}_{2}\right)$ are produced [16]. iNOS and COX-2 expression are regulated by NF- $\kappa \mathrm{B}$. NF- $\kappa \mathrm{B}$ is a transcription factor that regulates several genes, including iNOS, COX-2, IL-1 $\beta$, IL- 6 , and TNF- $\alpha$, which are important for immunity and LPS-induced inflammation [17]. NF- $\kappa \mathrm{B}$ is activated by phosphorylation of inhibitory $\kappa \mathrm{B} \alpha(\mathrm{I} \kappa \mathrm{B} \alpha)$ through activation of mitogen-activated protein kinases (MAPKs), such as cJun N-terminal kinase (JNK), p38, and extracellular signalregulated kinase (ERK)1/2 $[18,19]$. In the present study, we investigated the effects of $O$. japonicus on the expression of genes encoding pathogen-recognition receptors (TLR2, TLR4, NOD1, and NOD2) and proinflammatory factors (iNOS, COX-2, and cytokines) in LPS-stimulated PMA-differentiated THP-1 cells, as well as the NF- $\kappa \mathrm{B}$ and MAPK pathways.

\section{Materials and Methods}

2.1. Extraction of O. japonicus. O. japonicus (20 g) was extracted by overnight incubation at $60^{\circ} \mathrm{C}$ in $500 \mathrm{~mL}$ of $80 \%$ methanol. The solution was filtered through Whatman No. 1 filter paper and concentrated using a rotary evaporator (Buchi, Flawil, Switzerland). The concentrated extract was freeze-dried (EYELA, Tokyo, Japan) and stored at $4^{\circ} \mathrm{C}$ in a vacuum container until use.

2.2. Cell Culture. Human monocytic leukemia THP-1 cells were supplied by the Korean Cell Line Bank. Cells were cultured in RPMI 1640 medium (GIBCO, Grand Island, NY, USA) containing $10 \%$ fetal bovine serum and antibiotics. Cells were incubated at $37^{\circ} \mathrm{C}$ in a humidified atmosphere of $5 \% \mathrm{CO}_{2}$ in $95 \%$ air. THP-1 cells were treated with $100 \mathrm{nM}$ of phorbol myristate acetate (PMA, Sigma-Aldrich Co., St. Louis, MO, USA) for $72 \mathrm{~h}$ to induce differentiation into macrophages. After differentiation, nonattached cells were removed by aspiration and adherent macrophages were washed with RPMI 1640 medium three times and then incubated in cell culture medium at $37^{\circ} \mathrm{C}$.

2.3. Cell Viability. Cell proliferation was measured with CellTiter 96 Aqueous One Solution (Promega, Madison, WI, USA). Cells were seeded at $1 \times 10^{4}$ per well in 96-well plates and incubated with different concentrations of $O$. japonicus at $37^{\circ} \mathrm{C}$ for $24 \mathrm{~h}$, respectively. Cell viability was determined using a colorimetric assay with PMS/MTS solution. The absorbance was determined at $490 \mathrm{~nm}$ with background subtraction at $650 \mathrm{~nm}$.

2.4. Treatment with O. japonicus. THP-1 cells were pretreated for $2 \mathrm{~h}$ in serum-free medium with O. japonicus $(0-25 \mu \mathrm{g} / \mathrm{mL})$ and then incubated with LPS $(1 \mu \mathrm{g} / \mathrm{mL}$ ) for $4 \mathrm{~h}$ (for mRNA expression) and $20 \mathrm{~h}$ (for protein expression). At each time

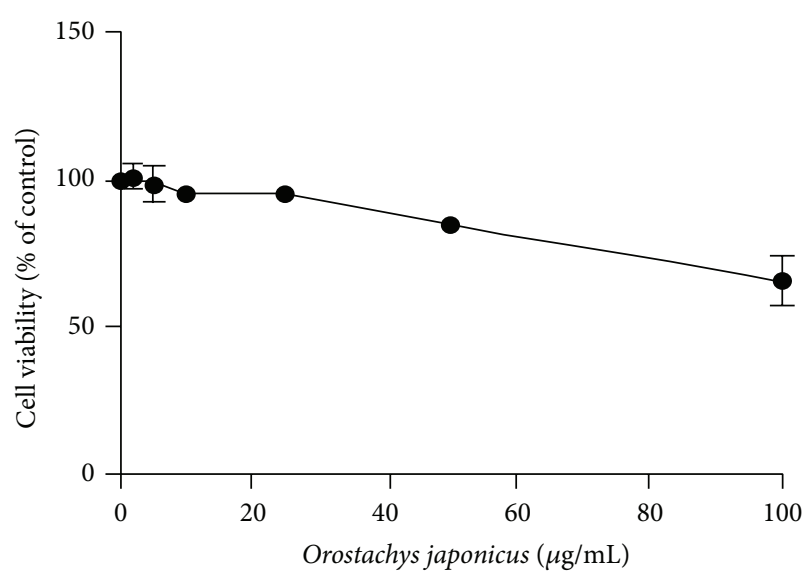

FIgURE 1: Effects of O. japonicus on the proliferation of THP-1 cells. Cells were treated with various concentrations of $O$. japonicus for $24 \mathrm{~h}$. Cell viability was then determined by MTT assay. The data represent the means \pm SD of triplicate samples.

point, total RNA and protein were isolated from the cultured THP-1 cells.

2.5. RNA Extraction and Real-Time PCR. Total RNA was purified from cultured cells using the TRIzol reagent following the manufacturer's protocol (Invitrogen, Carlsbad, CA, USA). First-strand cDNA synthesis was performed with $1 \mu \mathrm{g}$ of total RNA and it was transcribed to cDNA using a reverse transcription system with random hexamers (Promega) according to the manufacturer's protocol. The sequences for gene-specific primers were as follows: TLR2, $5^{\prime}$-TCTCCCATTTCCGTCTTTTT- $3^{\prime}$ and $5^{\prime}$-GGTCTTGGTGTTCATTATCTTC-3' (125 bp); TLR4, 5' -GAAGCTGGTGGCTGTGGA-3' and $5^{\prime}$-TGATGTAGAACCCGCAAG$3^{\prime}$ (213 bp); NOD1, 5' -GTCACTGAGGTCCATCTGAAC$3^{\prime}$ and $5^{\prime}$-CATCCACTCCTGGAAGAACCT- $3^{\prime}$ (363 bp); NOD2, $5^{\prime}$-CATGTGCTGCTACGTGTTCTC- $3^{\prime}$ and $5^{\prime}$ CCTGCCACAATTGAAGAGGTG-3' (226 bp); iNOS, $5^{\prime}$ TGGATGCAACCCCATTGTC- $3^{\prime}$ and $5^{\prime}$-CCCGCTGCCCCAGTTT-3' (59 bp); COX-2, $5^{\prime}$-CAAATCCTTGCTGTTCCCACCCAT- $3^{\prime}$ and $5^{\prime}$-GTGCACTGTGTTTGGAGTGGGTTT-3' (173 bp); IL-1 $\beta, 5^{\prime}$-TGATGGCTTATTACAGTGGCAATG-3' and $5^{\prime}$-GTAGTGGTGGTCGGAGATTCG-3' (140 bp); IL-6, 5'-GTGTTGCCTGCTGCCTTC$3^{\prime}$ and $5^{\prime}$-AGTGCCTCTTTGCTGCTTTC-3' (194 bp); IL-8, $5^{\prime}$-GACATACTCCAAACCTTTCCAC- $3^{\prime}$ and $5^{\prime}$-CTTCTCCACAACCCTCTGC- $3^{\prime}$ (160 bp); TNF- $\alpha, 5^{\prime}$-ATCTTCTCGAACCCCGAGTG- $3^{\prime}$ and $5^{\prime}$-GGGTTTGCTACAACATGGGC-3 $3^{\prime}$ (51 bp); $\beta$-actin, $5^{\prime}$-GCGAGAAGATGACCCAGATC- $3^{\prime}$ and $5^{\prime}$-GGATAGCACAGCCTGGATAG- $3^{\prime}$ (77 bp). Real-time PCR was performed on the StepOneplus realtime PCR system with Power SYBR Green PCR Master Mix (Applied Biosystems, Foster, CA, USA). PCR was performed with $1 \mu \mathrm{L}$ of cDNA in $20 \mu \mathrm{L}$ reaction mixtures that consisted of $10 \mu \mathrm{L}$ Power SYBR Green PCR Master Mix, $2 \mu \mathrm{L}$ primers, and $7 \mu \mathrm{L}$ PCR-grade water. The reactions were performed with a denaturation step at $95^{\circ} \mathrm{C}$ for $10 \mathrm{~min}$, followed by 40 cycles of $95^{\circ} \mathrm{C}$ for $15 \mathrm{sec}$ and $60^{\circ} \mathrm{C}$ for $1 \mathrm{~min}$. The crossing point 


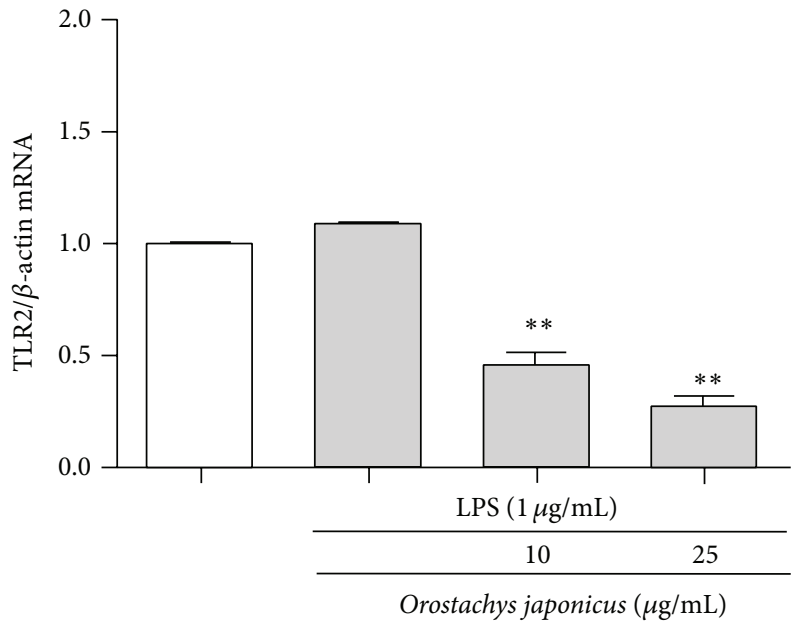

(a)

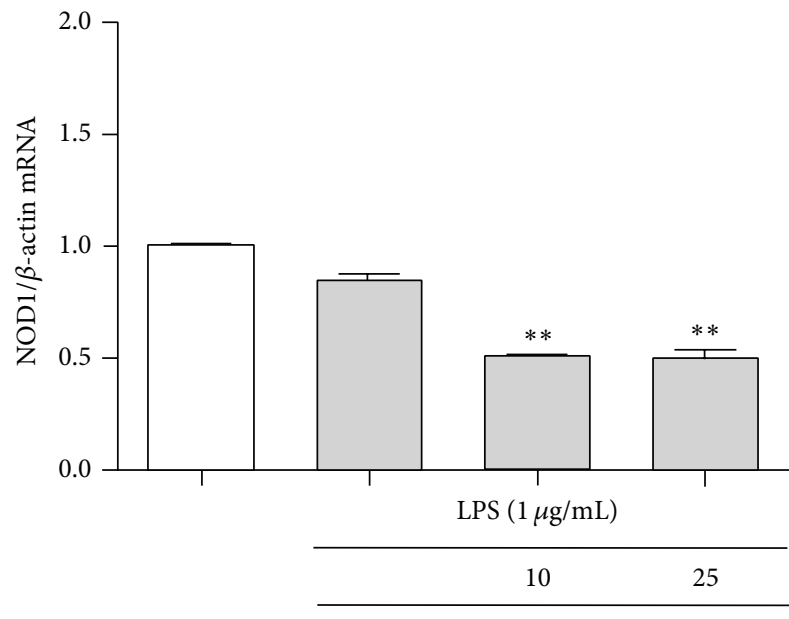

Orostachys japonicus $(\mu \mathrm{g} / \mathrm{mL})$

(c)

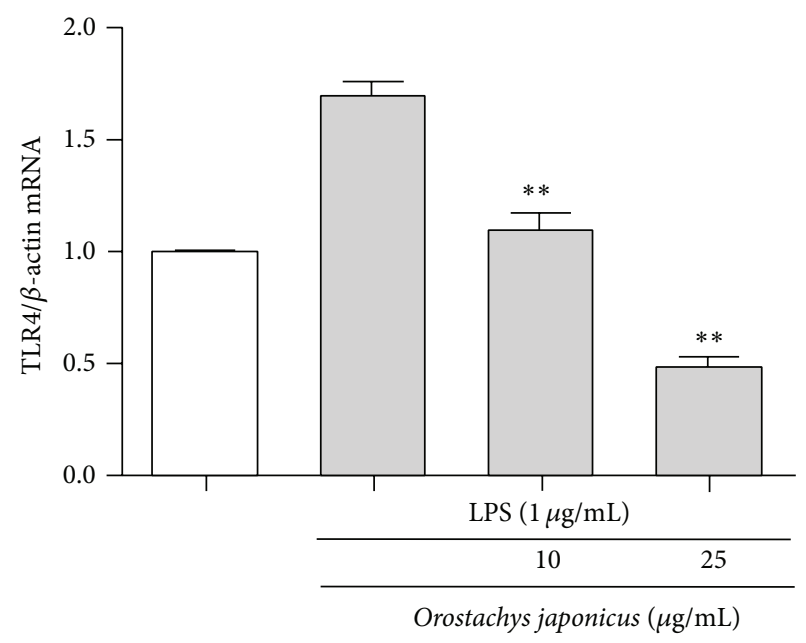

(b)

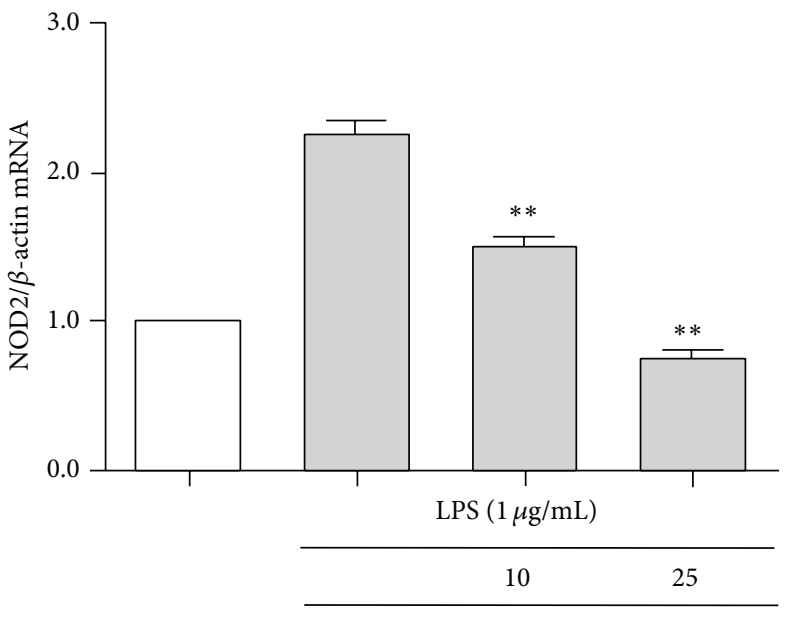

Orostachys japonicus $(\mu \mathrm{g} / \mathrm{mL})$

(d)

Figure 2: Effects of O. japonicus on LPS-induced TLR2, TLR4, NOD1, and NOD2 mRNA levels in THP-1 cells. Cells were pretreated for $20 \mathrm{~h}$ with various concentrations of $O$. japonicus $(10$ or $25 \mu \mathrm{g} / \mathrm{mL})$ before exposure to LPS $(1 \mu \mathrm{g} / \mathrm{mL})$ for $4 \mathrm{~h}$, and mRNA levels were measured using real-time PCR. The crossing points of the TLR2 (a), TLR4 (b), NOD1 (c), and NOD2 (d) with $\beta$-actin were entered into the formula $2^{- \text {(target gene- } \beta \text {-actin) }}$, and relative amounts were quantified. The data represent the means \pm SD of three independent samples. ${ }^{* *} P<0.01$ compared with LPS stimulation alone.

of target genes with $\beta$-actin was calculated using the formula $2^{-(\text {target gene- } \beta \text {-actin })}$, and the relative amounts were quantified.

2.6. Western Blot Analysis. Cells were collected and washed with cold PBS and then lysed using lysis buffer $(20 \mathrm{mM}$ Tris$\mathrm{HCl}$ (pH 7.5), $150 \mathrm{mM} \mathrm{NaCl}, 1 \mathrm{mM} \mathrm{Na}{ }_{2}$ EDTA, 1 mM EGTA, $1 \%$ Triton, $2.5 \mathrm{mM}$ sodium pyrophosphate, $1 \mathrm{mM} \beta$-glycerophosphate, $1 \mathrm{mM} \mathrm{Na}_{3} \mathrm{VO}_{4}$, and $1 \mu \mathrm{g} / \mathrm{mL}$ leupeptin) containing $1 \mathrm{mM}$ PMSF (Cell Signaling Technology, Inc., Boston, MA, USA). The protein concentration was determined using a BCA protein assay according to the manufacturer's protocol. Protein $(30 \mu \mathrm{g})$ was fractionated by $12 \%$ SDS-PAGE and transferred by electrophoresis to nitrocellulose membranes. The membranes were blocked with 5\% nonfat dry milk for $1 \mathrm{~h}$ at room temperature and then incubated overnight with antibodies against COX-2 (Santa Cruz Biotechnology, Santa Cruz, CA, USA), iNOS, NF- $\kappa$ B p 65 , phospho-NF- $\kappa$ B p65, I $\kappa \mathrm{B} \alpha$, phospho-I $\kappa \mathrm{B} \alpha$, JNK, phospho-JNK, p38 MAPK, phospho-p38 MAPK, ERK, phospho-ERK1/2 (Cell Signaling Technology), and $\beta$-actin (Sigma-Aldrich Co.), which were diluted to $1: 1,000$ with Tris-buffered saline containing $0.05 \%$ Tween 20 (TBS-T). After washing with TBS-T for $1 \mathrm{~h}$, the membranes were incubated for $1 \mathrm{~h}$ at room temperature with horseradish peroxidase-conjugated secondary antibodies diluted to $1: 2,500$ in TBS-T. The membranes were subsequently washed with TBS-T for $1 \mathrm{~h}$ and proteins were detected using an Enhanced Chemiluminescence Kit (Thermo Scientific, Protein biology, IL, USA). Protein expression was analyzed using a Davinch-Chemi Chemiluminescence Imaging System (Davinch-K Co., Ltd., Seoul, Korea). 


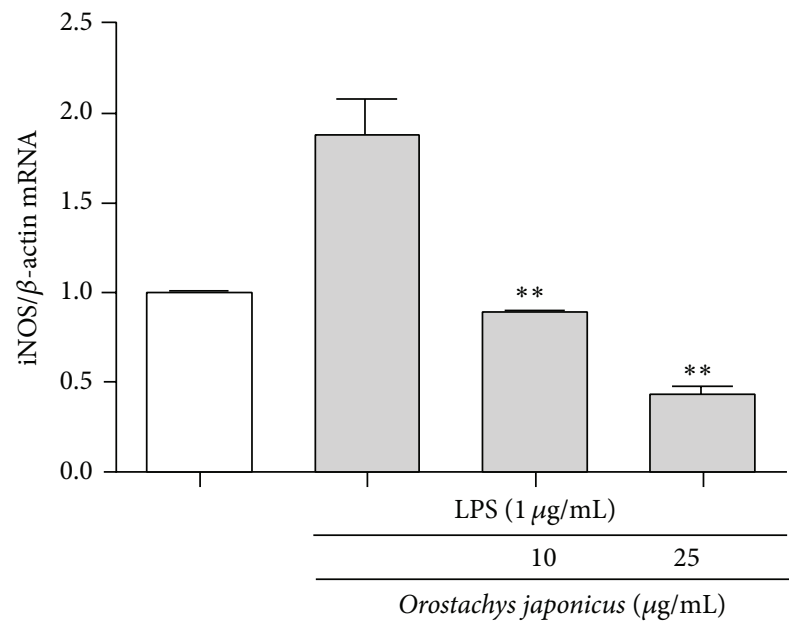

(a)

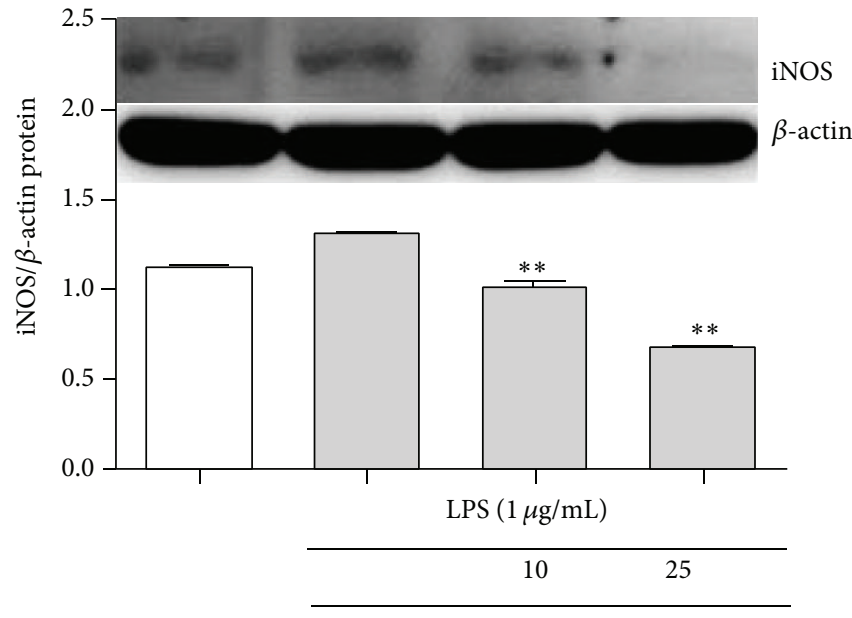

Orostachys japonicus $(\mu \mathrm{g} / \mathrm{mL})$

(c)

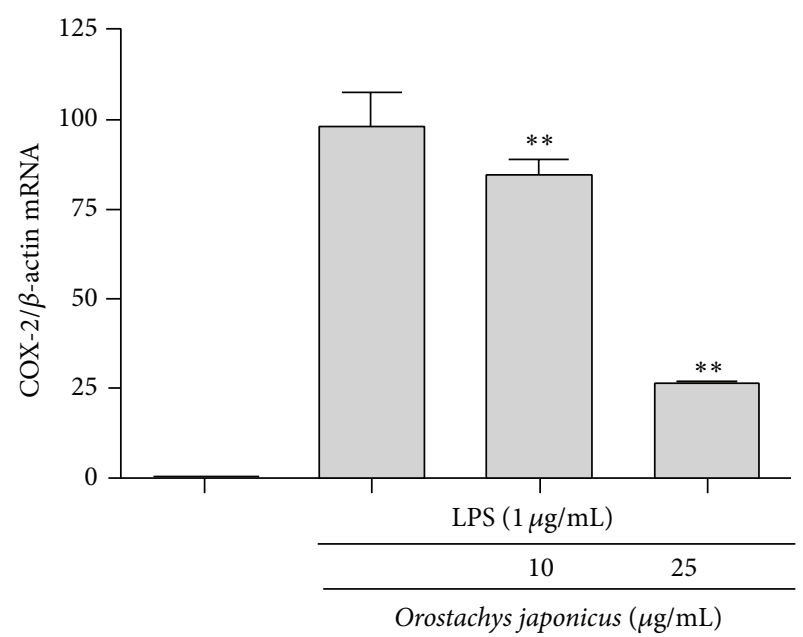

(b)

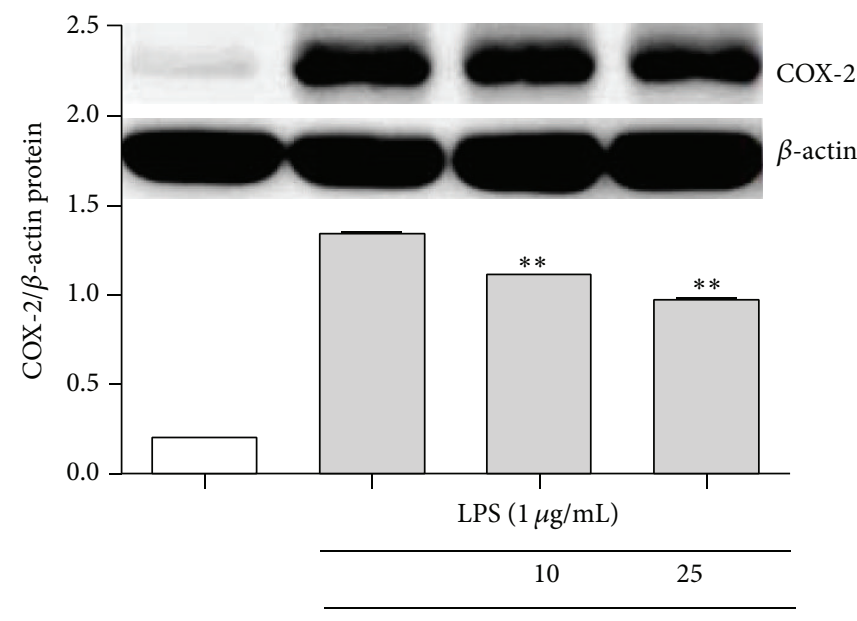

Orostachys japonicus $(\mu \mathrm{g} / \mathrm{mL})$

(d)

Figure 3: Effects of O. japonicus on LPS-induced iNOS and COX-2 mRNA and protein expression in THP-1 cells. Cells were pretreated for $20 \mathrm{~h}$ with various concentrations of O. japonicus (10 or $25 \mu \mathrm{g} / \mathrm{mL}$ ) before exposure to LPS ( $1 \mu \mathrm{g} / \mathrm{mL}$ ) for 4 h. Levels of (a) iNOS and (b) COX-2 mRNA were measured using real-time PCR. The crossing points of iNOS and COX-2 with $\beta$-actin were entered into the formula $2^{\text {-(target gene- } \beta \text {-actin) }}$, and relative amounts were quantified. iNOS (c) and COX-2 (d) protein levels were determined by immunoblotting. Densitometric analyses are presented as the relative ratios of iNOS and COX-2 with $\beta$-actin. The data represent the means \pm SD of three independent samples. ${ }^{* *} P<0.01$ compared with LPS stimulation alone.

2.7. Statistical Analysis. Values were expressed as means \pm SD. Student's $t$-test was used to evaluate differences between the LPS-only treated samples and LPS plus O. japonicus treated samples. ${ }^{*} P<0.05$ and ${ }^{* *} P<0.01$ were considered to indicate statistical significance.

\section{Results}

3.1. O. japonicus Suppressed Cell Viability. The cytotoxicity of O. japonicus to THP-1 cells was examined by exposing cells to various concentrations of O. japonicus for $24 \mathrm{~h}$. Cell viability was measured using the PMS/MTS assay. O. japonicus showed no toxicity at low concentrations (Figure 1).
3.2. O. japonicus Inhibited the LPS-Induced Expression of the TLR2, TLR4, NOD1, and NOD2 Genes. We investigated the effect of $O$. japonicus on the expression of TLR2, TLR4, NOD1, and NOD2 in THP-1 cells. mRNA levels were analyzed using real-time PCR. LPS induced TLR4 and NOD2 expression compared to the control. O. japonicus suppressed LPSinduced TLR4 and NOD2 transcription (Figures 2(b) and $2(\mathrm{~d})$ ). In contrast, TLR2 and NOD1 mRNA levels were not significantly affected after LPS stimulation (Figures 2(a) and 2(c)).

3.3. O. japonicus Inhibited LPS-Induced iNOS and COX-2 Gene Expression. We explored the effect of O. japonicus on inflammatory mediator expression. As shown in Figure 3, 


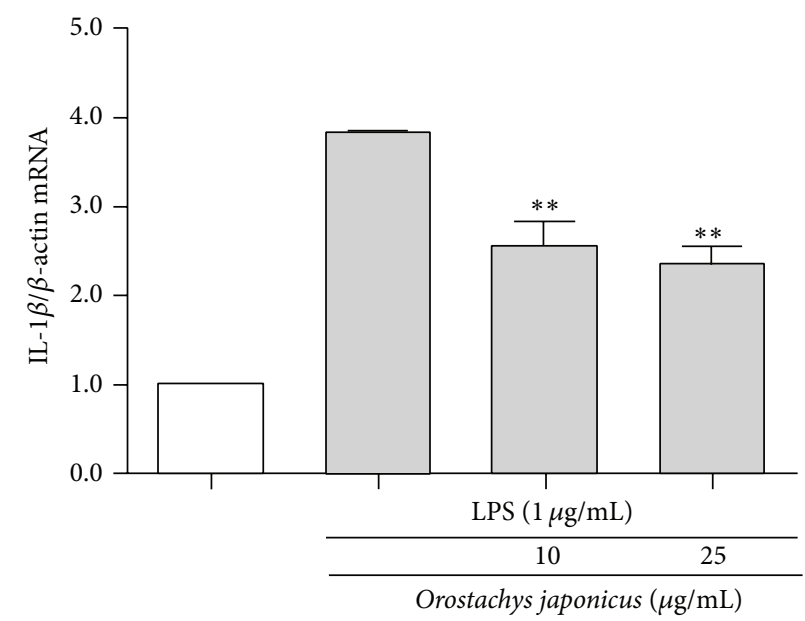

(a)

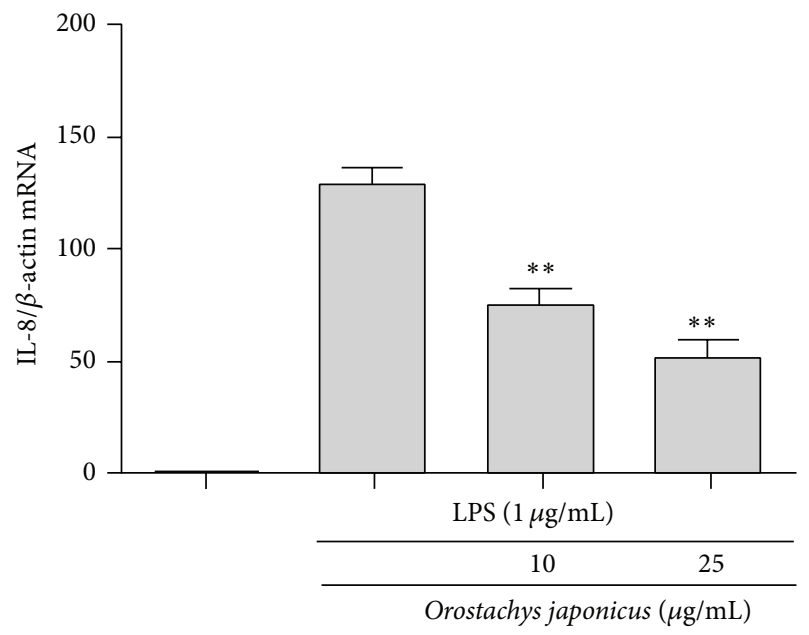

(c)

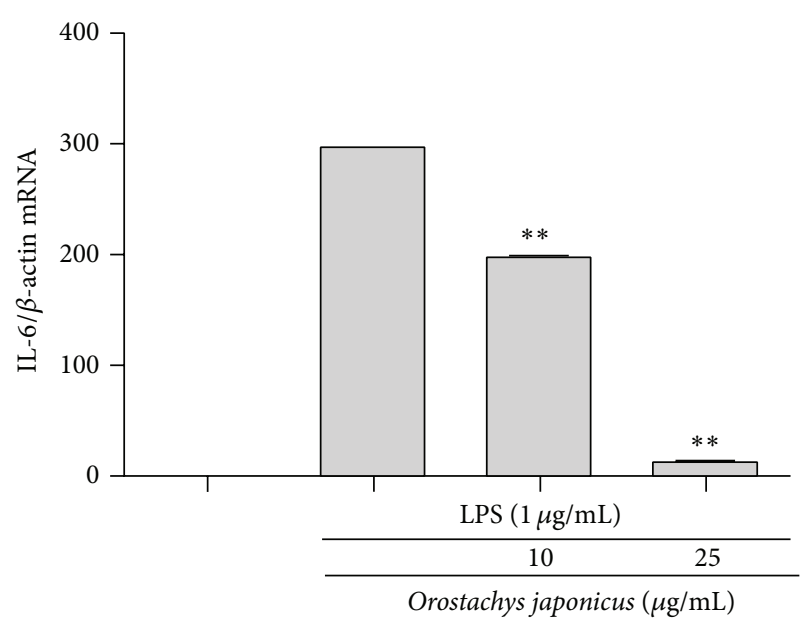

(b)

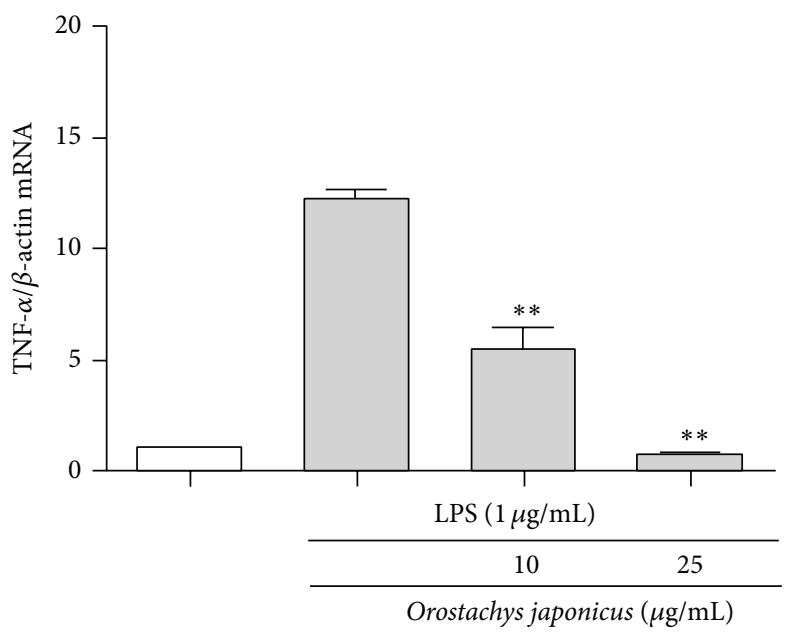

(d)

FIGURE 4: Effects of O. japonicus on LPS-induced cytokine mRNA levels in THP-1 cells. Cells were pretreated for $20 \mathrm{~h}$ with various concentrations of $O$. japonicus (10 or $25 \mu \mathrm{g} / \mathrm{mL})$ before exposure to LPS $(1 \mu \mathrm{g} / \mathrm{mL})$ for $4 \mathrm{~h}$, and mRNA levels were measured using real-time PCR. The crossing points of the IL-1 $\beta$ (a), IL-6 (b), IL-8 (c), and TNF- $\alpha$ (d) with $\beta$-actin were entered into the formula $2^{-(\text {target gene- } \beta \text {-actin) }}$, and relative amounts were quantified. The data represent the means \pm SD of three independent samples. ${ }^{* *} P<0.01$ compared with LPS stimulation alone.

the response was dose-dependent, and the effect was significant at $>10 \mu \mathrm{g} / \mathrm{mL}$ O. japonicus. We evaluated whether $O$. japonicus affected iNOS and COX-2 mRNA transcription and protein levels. mRNA and protein levels were measured using real-time PCR and western blot analysis, respectively. LPS induced iNOS and COX-2 gene expression compared to the control. O. japonicus suppressed LPS-induced iNOS and COX-2 transcription (Figures 3(a) and 3(b)) and translation (Figures 3(c) and 3(d)).

3.4. O. japonicus Inhibited LPS-Induced IL-1 $\beta, I L-6, I L-8$, and TNF- $\alpha$ Expression. We evaluated proinflammatory cytokine transcription in LPS-stimulated THP-1 cells. IL-1 $\beta$, IL-6, IL8 , and TNF- $\alpha$ mRNA levels were evaluated using real-time PCR. LPS induced IL- $1 \beta$, IL-6, IL- 8 , and TNF- $\alpha$ mRNA levels compared to the control. O. japonicus suppressed the
LPS-induced IL-1 $\beta$ (Figure 4(a)), IL-6 (Figure 4(b)), IL-8 (Figure 4(c)), and TNF- $\alpha$ (Figure 4(d)) transcription.

3.5. O. japonicus Inhibited LPS-Induced NF- $\kappa B$ Signaling and $I \kappa B \alpha$ Degradation. We next investigated the inhibition of $\mathrm{NF}-\kappa \mathrm{B}$ p 65 activity. The effects of O. japonicus on $\mathrm{I} \kappa \mathrm{B} \alpha$ degradation were examined. NF- $\kappa \mathrm{B}$ p 65 and $\mathrm{I} \kappa \mathrm{B} \alpha$ protein levels were determined by western blot analysis. Treatment with LPS alone increased the phosphorylation of NF- $\kappa \mathrm{B}$ p 65 and $\mathrm{I} \kappa \mathrm{B} \alpha$, while $O$. japonicus inhibited LPS-induced phosphorylation of NF- $\kappa \mathrm{B}$ p 65 (Figures $5(\mathrm{a})$ and $5(\mathrm{c})$ ) and $\mathrm{I} \kappa \mathrm{B} \alpha$ (Figures 5(b) and 5(d)) in a dose-dependent manner.

3.6. O. japonicus Inhibited LPS-Induced Phosphorylation of JNK, p38 MAPK and ERK1/2. To investigate the molecular mechanism underlying NF- $\kappa \mathrm{B}$ inhibition by $O$. japonicus in 


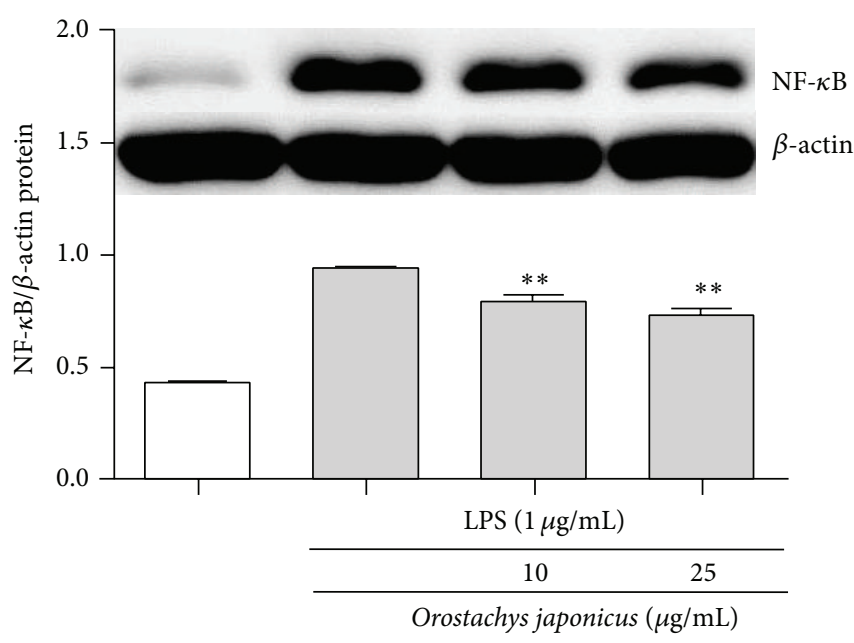

(a)

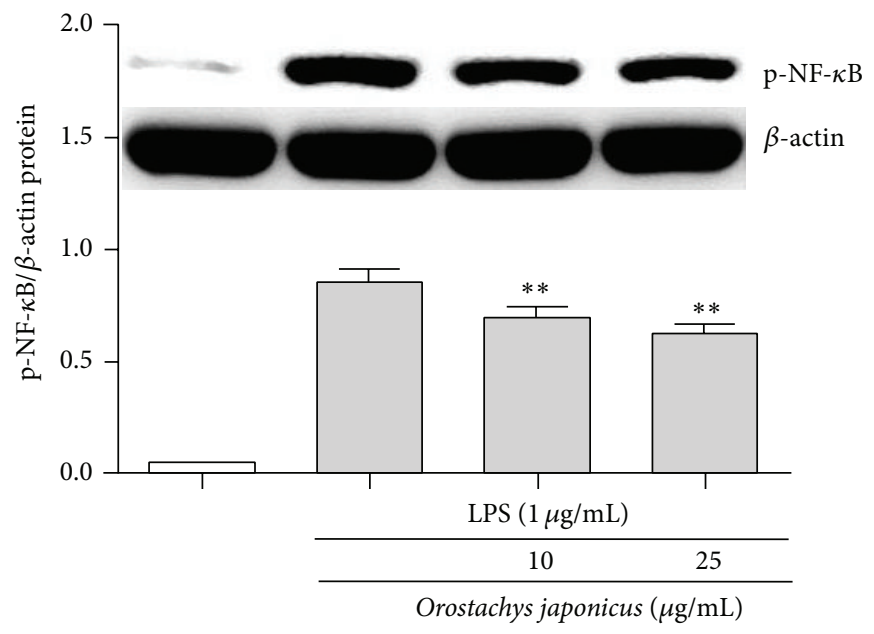

(c)

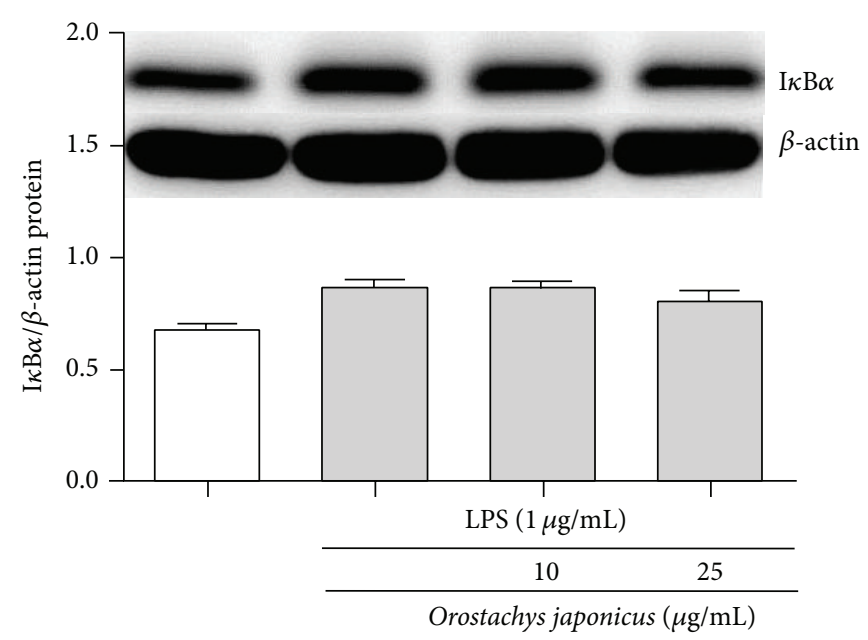

(b)

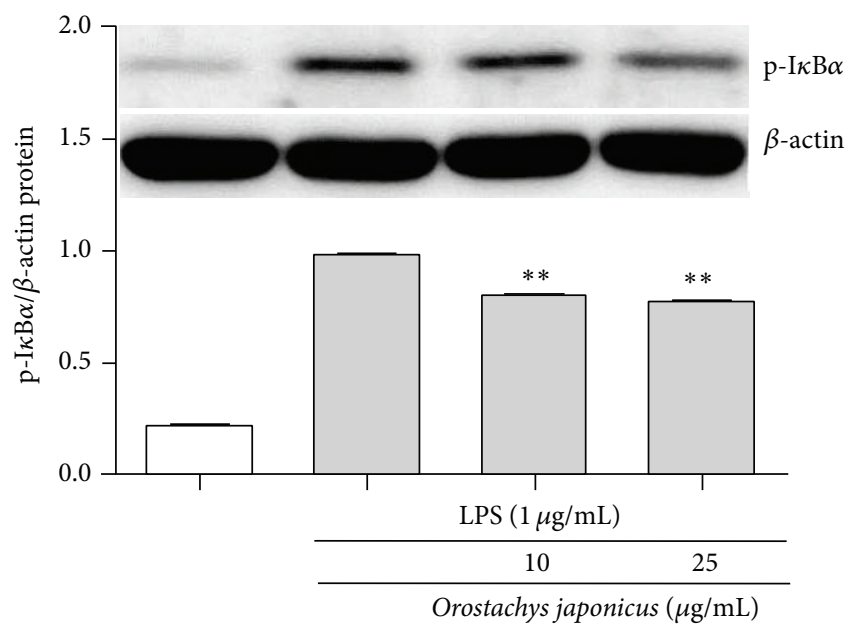

(d)

FiguRE 5: Effects of $O$. japonicus on LPS-induced NF- $\kappa \mathrm{B}$ p 65 phosphorylation and $\mathrm{I} \kappa \mathrm{B} \alpha$ degradation in THP- 1 cells. Cells were pretreated for $20 \mathrm{~h}$ with various concentrations of $O$. japonicus $(10$ or $25 \mu \mathrm{g} / \mathrm{mL})$ before exposure to LPS $(1 \mu \mathrm{g} / \mathrm{mL})$ for $4 \mathrm{~h}$, and NF- $\kappa \mathrm{B}$ p 65 and I $\kappa \mathrm{B} \alpha$ protein levels were determined using immunoblotting. Densitometric analyses were presented as the relative ratios of NF- $\kappa \mathrm{B}$ p 65 (a) or p-NF- $\kappa \mathrm{B}$ p65 (c) and $\mathrm{I} \kappa \mathrm{B} \alpha(\mathrm{b})$ or $\mathrm{p}-\mathrm{I} \kappa \mathrm{B} \alpha$ (d) to $\beta$-actin. The data represent the means $\pm \mathrm{SD}$ of three independent samples. ${ }^{* *} P<0.01$ compared with LPS stimulation alone.

LPS-stimulated cells, we examined the effects of $O$. japonicus on the activation of JNK, p38 MAPK, and ERK1/2. MAPKs were assessed by western blot analysis. The phosphorylation of JNK, p38 MAPK, and ERK1/2 increased in cells treated with LPS alone. O. japonicus inhibited the phosphorylation of JNK (Figures 6(a) and 6(d)), p38 MAPK (Figures 6(b) and 6(e)), and ERK1/2 (Figures 6(c) and 6(f)) in LPS-stimulated cells in a dose-dependent manner.

\section{Discussion}

In the present study, we demonstrated that O. japonicus inhibits LPS-induced inflammatory signals in the PMAdifferentiated human THP-1 cells. To evaluate the antiinflammatory effects of $O$. japonicus, cells were pretreated with O. japonicus and then stimulated with LPS. O. japonicus exhibited dose-dependent cytotoxicity. Cell viability was not affected by $24 \mathrm{~h}$ treatment with less than $50 \mu \mathrm{g} / \mathrm{mL}$ O. japonicus. Therefore, in the subsequent experiments $10-25 \mu \mathrm{g} / \mathrm{mL}$ O. japonicus was used.

TLRs are expressed predominantly in monocytes/macrophages and neutrophils [20]. TLR2 and TLR4 are transmembrane receptors that transmit LPS signals to intracellular components in signal transduction pathways and play important roles in the immune system. TKR4 is associated with the recognition of Gram-negative bacterial LPS, and TLR2 is considered the receptor for Gram-positive bacteria [21]. While O. japonicus was shown to express both TLR2 and TLR4 in the present study, in the presence of LPS, TLR2 expression was higher than that of TLR4. Our findings suggest that $O$. japonicus could elicit inflammatory reactions in PMA-activated THP-1 cells and contribute to inflammatory processes, a process mediated by TLR 4 and, to a lesser extent, TLR2. The 


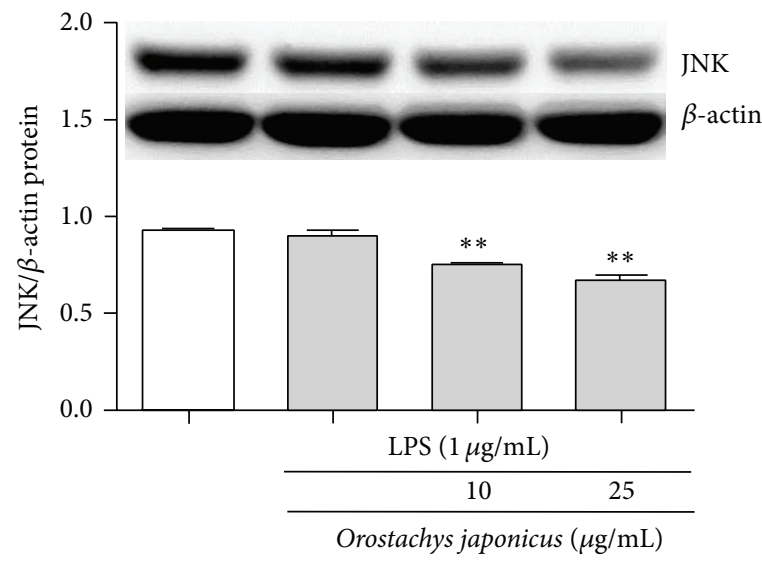

(a)

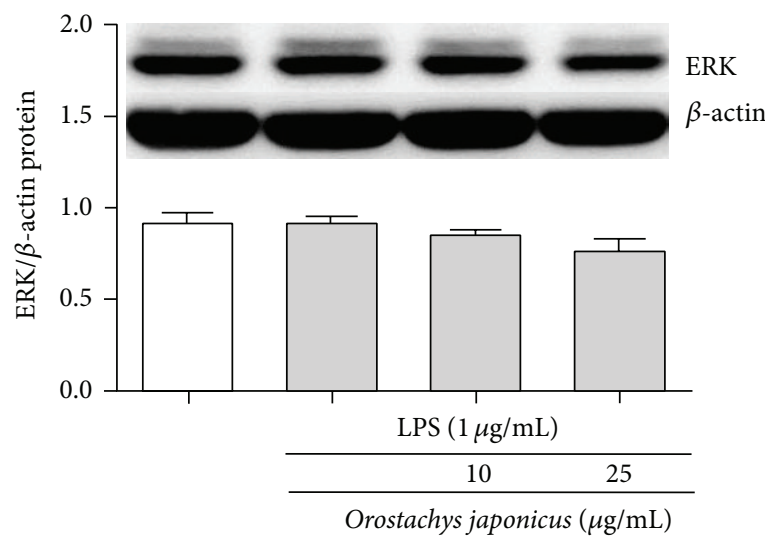

(c)

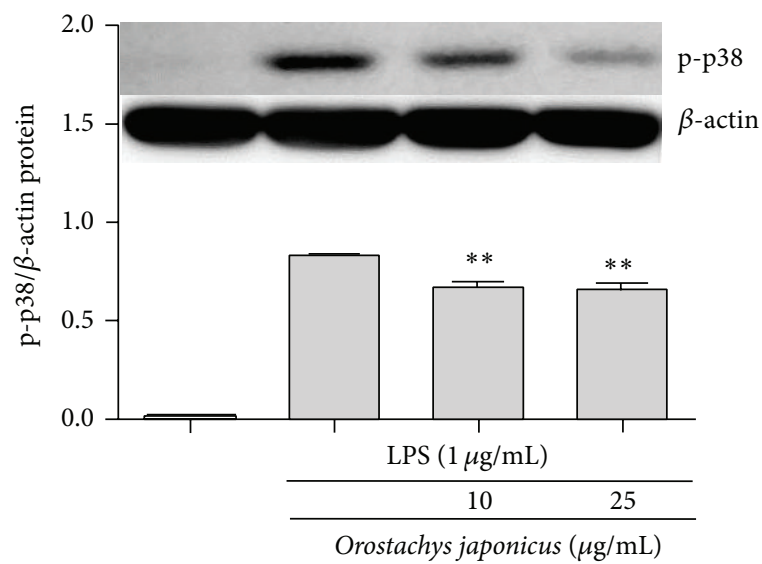

(e)

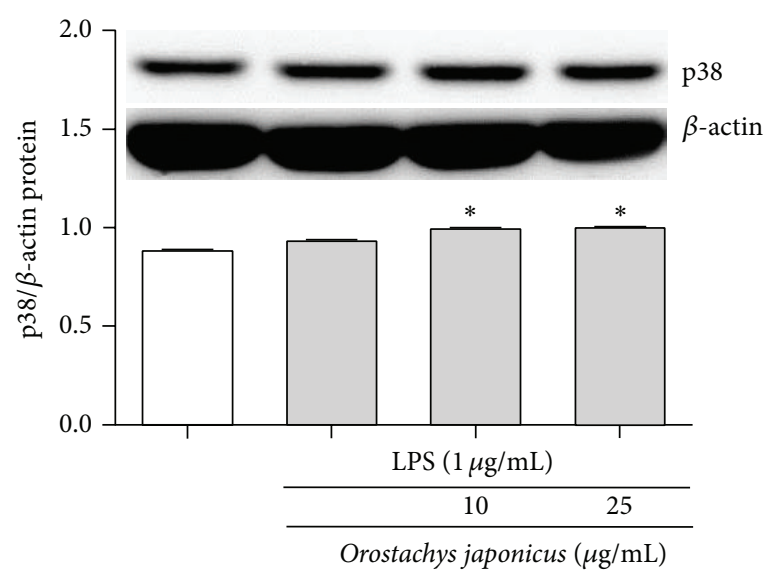

(b)

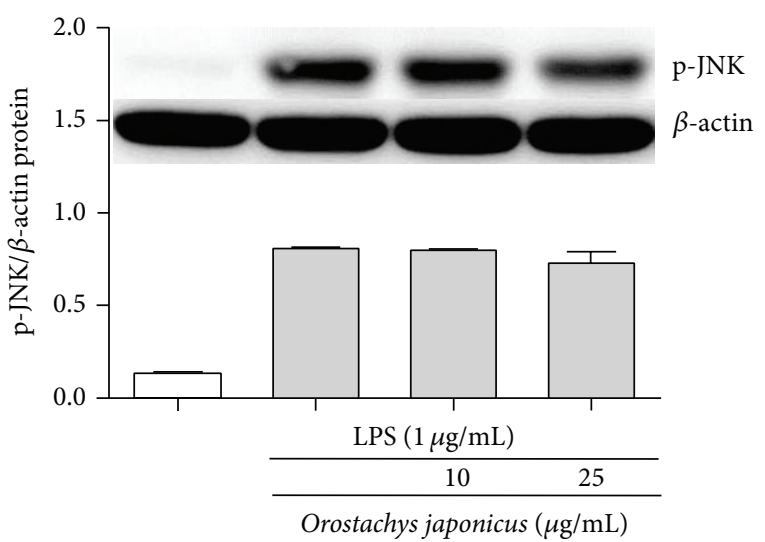

(d)

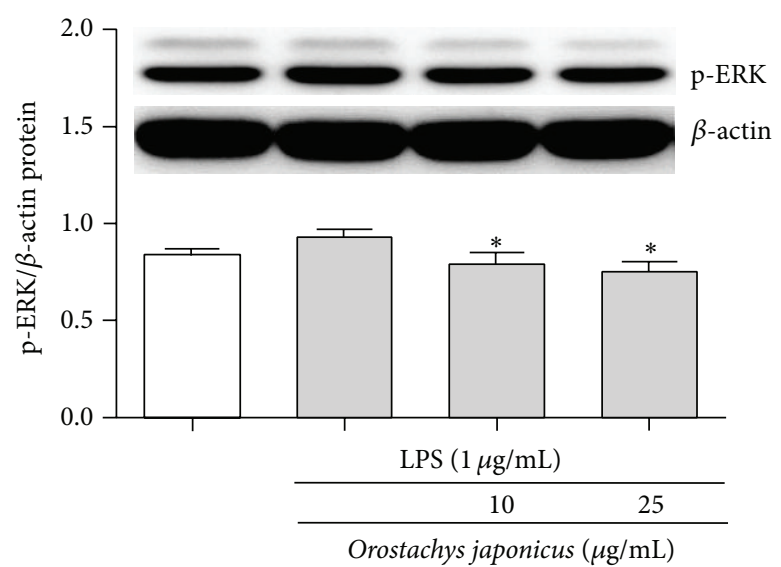

(f)

FIGURE 6: Effects of O. japonicus on the LPS-induced phosphorylation of JNK, p38 MAPK, and ERK in THP-1 cells. Cells were pretreated for $20 \mathrm{~h}$ with various concentrations of $O$. japonicus $(10$ or $25 \mu \mathrm{g} / \mathrm{mL}$ ) before exposure to LPS $(1 \mu \mathrm{g} / \mathrm{mL})$ for $4 \mathrm{~h}$, and JNK, p38 MAPK, and ERK protein levels were determined by immunoblotting. Densitometric analyses are presented as the relative ratios of JNK (a) or p-JNK (d), p38 MAPK (b) or p-p38 MAPK (e), and ERK (c) or p-ERK (f) to $\beta$-actin. The data represent the means \pm SD of three independent samples. ${ }^{*} P<0.05$ and ${ }^{* *} P<0.01$ compared with LPS stimulation alone.

peptidoglycan subunits are recognized by the NOD family proteins, in particular by NOD2. NOD2 is an intracellular protein involved in innate immunity and is associated with chronic inflammatory diseases in humans [22]. We found that
O. japonicus downregulated LPS-induced NOD2 expression, with no effect on NOD1. Taken together, these results suggest that $O$. japonicus mediated inflammatory reactions through TLR4 and NOD2. 
iNOS and COX-2 are important enzymes that mediate inflammatory processes and have been associated with the pathogenesis of certain types of human cancers, as well as inflammatory disorders [23]. Since proper regulation of iNOS and COX-2 expression could provide an effective and promising approach to treat inflammation related to diseases, much effort has been made to identify iNOS and COX-2 modulators, especially from plant sources $[24,25]$. The present study demonstrates that $O$. japonicus extract can effectively suppress transcription and translational levels of iNOS and COX2 expression. In addition, O. japonicus inhibited cytokine (IL1, IL-6, IL-8, and TNF- $\alpha$ ) expression in THP-1 cells stimulated by LPS. We evaluated transcription of proinflammatory cytokines, including IL-1 $\beta$, IL-6, IL- 8 , and TNF- $\alpha$, which play pivotal roles in the development and progression of inflammation, in LPS-stimulated cells. Our findings further suggest that $O$. japonicus possesses potent anti-inflammatory activity. Harpagophytum procumbens suppresses LPS-stimulated expression of iNOS and COX-2 in the fibroblast cell line L929 [26] and inhibits LPS-induced release of cytokines (IL$1 \beta$, IL- 6 , and TNF- $\alpha$ ) and $\mathrm{PGE}_{2}$ from human monocytes [27]. Arisaema cum bile extract inhibits the production of proinflammatory cytokines, including IL-1, IL-6, and TNF$\alpha$, and also inhibits iNOS and COX-2 expression, which are responsible for the production of $\mathrm{NO}$ and $\mathrm{PGE}_{2}$ in THP-1 cells [28]. The dichloromethane fraction from O. japonicus (OJD) inhibited NO production and TLR4, IL-1 $\beta$, iNOS, and COX-2 expression in LPS-stimulated murine RAW 264.7 macrophage cells and inhibited LPS-induced NF- $\kappa \mathrm{B}$ p 65 activation by suppressing $\mathrm{I} \kappa \mathrm{B} \alpha$ phosphorylation. However, phosphorylation of JNK and p38 MAPK was suppressed by OJD in a dose-dependent manner in LPS-stimulated cells [29]. Harpagoside inhibited LPS-stimulated NF- $\kappa$ B promoter activity based on a gene reporter in RAW 264.7 cells, indicating that harpagoside interfered with the activation of gene transcription. These results suggest that the inhibition of iNOS and COX-2 expression by harpagoside suppresses NF- $\kappa \mathrm{B}$ activation [30]. Inhibition of the NF- $\kappa \mathrm{B}$ and MAPK pathways has been proposed to be a major mechanism underlying the attenuation of LPS-induced inflammatory cytokine production. NF- $\kappa \mathrm{B}$ plays a crucial role as the transcription factor in regulating many of the proinflammatory cytokine genes. LPS stimulation elicits a cascade leading to the activation of NF- $\kappa \mathrm{B}$ [31]. Cryptotanshinone suppressed LPS-induced production of IL- 6 and TNF- $\alpha$ by inhibiting the activation of NF- $\kappa$ B and MAPKs [32]. MAPKs, such as JNK, p38 MAPK, and ERK, mediate the signal transduction involved in cell proliferation, differentiation, transformation, survival, and death [33].

Expression of the NO, TNF- $\alpha$, and IL- 6 genes is dependent on activation of the transcription factor NF- $\kappa \mathrm{B}$, which plays a crucial role in immune and inflammatory responses [34]. Activation of NF- $\kappa \mathrm{B}$ requires phosphorylation and proteolytic degradation of the inhibitory protein $\mathrm{I} \kappa \mathrm{B} \alpha$, an endogenous inhibitor that binds to NF- $\kappa \mathrm{B}$ in the cytoplasm [35]. Upon stimulation with LPS, NF- $\kappa \mathrm{B}$ is activated and translocated into the nucleus as a result of phosphorylationmediated degradation of $\mathrm{I} \kappa \mathrm{B} \alpha$ proteins in the lung of AL1 mice. However, pretreatment with a suitable drug could decrease the degradation of $\mathrm{I} \kappa \mathrm{B} \alpha$ and nuclear translocation of NF- $\kappa$ B p 65 and, therefore, downstream TNF- $\alpha$ and IL- 6 production. However, MAPKs including JNK, p38 MAPK, and ERK play an important role in signal transduction pathways and regulate cytokine release [36]. In this study, MAPK was activated in LPS-induced THP-1 cells. However, drug treatment markedly suppressed LPS-induced phosphorylation of JNK, p38 MAPK, and ERK. The inhibition of IL-1 $\beta$, IL-6, IL-8, and TNF- $\alpha$ production by $O$. japonicus occurs through pathways that converge on p38 MAPK and $\mathrm{I} \kappa \mathrm{B} \alpha$ activation since these kinases are known to regulate cytokine production in LPS-induced THP-1 cells. O. japonicus inhibits anti-inflammatory responses by inhibiting the degradation of $\mathrm{I} \kappa \mathrm{B} \alpha$ and nuclear translocation of $\mathrm{NF}-\kappa \mathrm{B}$ and downstream cytokine expression. These results suggest that drug activity was dependent in part on the inhibition of MAPK and NF$\kappa \mathrm{B}$ signaling pathways.

\section{Conclusion}

In this study, we found that treatment with O. japonicus blocked the activation of JNK, p38 MAPK, and ERK1/2, suggesting that $O$. japonicus suppresses LPS-induced NF$\kappa \mathrm{B}$ translocation by inhibiting the activation of these intracellular signaling cascades and reducing iNOS and COX-2 expression.

\section{Conflict of Interests}

The authors declare that there is no conflict of interests regarding the publication of this paper.

\section{References}

[1] C. J. Ma, W. J. Jung, K. Y. Lee, Y. C. Kim, and S. H. Sung, "Calpain inhibitory flavonoids isolated from Orostachys japonicus," Journal of Enzyme Inhibition and Medicinal Chemistry, vol. 24, no. 3, pp. 676-679, 2009.

[2] H. J. Park, S. H. Moon, K. Y. Park et al., "Antimutagenic effect of Orostachys japonicus," Journal of the Pharmaceutical Society of Korea, vol. 35, pp. 253-257, 1991.

[3] J.-H. Jeong, D.-S. Ryu, D.-H. Suk, and D.-S. Lee, "Antiinflammatory effects of ethanol extract from Orostachys japonicus on modulation of signal pathways in LPS-stimulated RAW 264.7 cells," BMB Reports, vol. 44, no. 6, pp. 399-404, 2011.

[4] S. Akira and H. Hemmi, "Recognition of pathogen-associated molecular patterns by TLR family," Immunology Letters, vol. 85, no. 2, pp. 85-95, 2003.

[5] I. Sabroe, R. C. Read, M. K. B. Whyte, D. H. Dockrell, S. N. Vogel, and S. K. Dower, "Toll-like receptors in health and disease: complex questions remain," The Journal of Immunology, vol. 171, no. 4, pp. 1630-1635, 2003.

[6] D. N. Cook, D. S. Pisetsky, and D. A. Schwartz, "Toll-like receptors in the pathogenesis of human disease," Nature Immunology, vol. 5, no. 10, pp. 975-979, 2004.

[7] W. Strober, P. J. Murray, A. Kitani, and T. Watanabe, "Signalling pathways and molecular interactions of NOD1 and NOD2," Nature Reviews Immunology, vol. 6, no. 1, pp. 9-20, 2006. 
[8] S. Akira, K. Takeda, and T. Kaisho, "Toll-like receptors: critical proteins linking innate and acquired immunity," Nature Immunology, vol. 2, no. 8, pp. 675-680, 2001.

[9] R. Medzhitov, “Toll-like receptors and innate immunity," Nature Reviews Immunology, vol. 1, no. 2, pp. 135-145, 2001.

[10] G. M. Barton and R. Medzhitov, "Toll-like receptor signaling pathways," Science, vol. 300, no. 5625, pp. 1524-1525, 2003.

[11] A. Poltorak, X. He, I. Smirnova et al., "Defective LPS signaling in $\mathrm{C} 3 \mathrm{H} / \mathrm{HeJ}$ and $\mathrm{C} 57 \mathrm{BL} / 10 \mathrm{ScCr}$ mice: mutations in Tlr4 gene," Science, vol. 282, no. 5396, pp. 2085-2088, 1998.

[12] M. S. Lee and Y.-J. Kim, "Signaling pathways downstream of pattern-recognition receptors and their cross talk," Annual Review of Biochemistry, vol. 76, pp. 447-480, 2007.

[13] M. J. Kim and Y. K. Cho, "Pattern recognition receptors in immune modulation," Biowave, vol. 8, pp. 1-22, 2006.

[14] D. C. Rockey, J. J. Chung, C. M. McKee, and P. W. Noble, "Stimulation of inducible nitric oxide synthase in rat liver by hyaluronan fragments," Hepatology, vol. 27, no. 1, pp. 86-92, 1998.

[15] C. Giuliani, G. Napolitano, I. Bucci, V. Montani, and F. Monaco, "NF- $\kappa \mathrm{B}$ transcription factor: role in the pathogenesis of inflammatory, autoimmune, and neoplastic diseases and therapy implications," Clinica Terapeutica, vol. 152, no. 4, pp. 249-253, 2001.

[16] J.-B. Méric, S. Rottey, K. Olaussen et al., "Cyclooxygenase-2 as a target for anticancer drug development," Critical Reviews in Oncology/Hematology, vol. 59, no. 1, pp. 51-64, 2006.

[17] P. J. Barnes and M. Karin, "Nuclear factor- $\kappa$ B: a pivotal transcription factor in chronic inflammatory diseases," The New England Journal of Medicine, vol. 336, no. 15, pp. 1066-1071, 1997.

[18] Y. E. Choi, H. Ahn, and J.-H. Ryu, "Polyacetylenes from Angelica gigas and their inhibitory activity on nitric oxide synthesis in activated macrophages," Biological \& Pharmaceutical Bulletin, vol. 23, no. 7, pp. 884-886, 2000.

[19] J.-H. Kim, J.-H. Jeong, S.-T. Jeon et al., "Decursin inhibits induction of inflammatory mediators by blocking nuclear factor- $\kappa \mathrm{B}$ activation in macrophages," Molecular Pharmacology, vol. 69, no. 6, pp. 1783-1790, 2006.

[20] A. Aderem and R. J. Ulevitch, "Toll-like receptors in the induction of the innate immune response," Nature, vol. 406, no. 6797, pp. 782-787, 2000.

[21] D. M. Underhill and A. Ozinsky, "Toll-like receptors: key mediators of microbe detection," Current Opinion in Immunology, vol. 14, no. 1, pp. 103-110, 2002.

[22] J. W. Dugan, A. Albor, L. David et al., "Nucleotide oligomerization domain- 2 interacts with $2^{\prime}-5^{\prime}$-oligoadenylate synthetase type 2 and enhances RNase-L function in THP-1 cells," Molecular Immunology, vol. 47, no. 2-3, pp. 560-566, 2009.

[23] Y.-J. Surh, K.-S. Chun, H.-H. Cha et al., "Molecular mechanisms underlying chemopreventive activities of anti-inflammatory phytochemicals: down-regulation of COX-2 and iNOS through suppression of NF- $\kappa$ B activation," Mutation Research, vol. 480481, pp. 243-268, 2001.

[24] H. S. Ban, S. S. Lim, K. Suzuki et al., "Inhibitory effects of furanocoumarins isolated from the roots of Angelica dahurica on prostaglandin $\mathrm{E}_{2}$ production," Planta Medica, vol. 69, no. 5, pp. 408-412, 2003.

[25] C. M. Lin, S. T. Huang, Y. C. Liang et al., "Isovitexin suppresses lipopolysaccharide-mediated inducible nitric oxide synthase through inhibition of NF-kappa B in mouse macrophages," Planta Medica, vol. 71, no. 8, pp. 748-753, 2005.
[26] M.-H. Jang, S. Lim, S.-M. Han et al., "Harpagophytum procumbens suppresses lipopolysaccharide-stimulated expressions of cyclooxygenase- 2 and inducible nitric oxide synthase in fibroblast cell line L929," Journal of Pharmacological Sciences, vol. 93, no. 3, pp. 367-371, 2003.

[27] B. L. Fiebich, M. Heinrich, K. O. Hiller, and N. Kammerer, "Inhibition of TNF- $\alpha$ synthesis in LPS-stimulated primary human monocytes by Harpagophytum extract SteiHap 69," Phytomedicine, vol. 8, no. 1, pp. 28-30, 2001.

[28] C.-B. Ahn and J.-Y. Je, "Anti-inflammatory activity of the oriental herb medicine, Arisaema cum Bile, in LPS-induced PMA-differentiated THP-1 cells," Immunopharmacology and Immunotoxicology, vol. 34, no. 3, pp. 379-384, 2012.

[29] H.-S. Lee, D.-S. Ryu, G.-S. Lee, and D.-S. Lee, "Anti-inflammatory effects of dichloromethane fraction from Orostachys japonicus in RAW 264.7 cells: suppression of NF- $\kappa$ B activation and MAPK signaling," Journal of Ethnopharmacology, vol. 140, no. 2, pp. 271-276, 2012.

[30] T. H.-W. Huang, V. H. Tran, R. K. Duke et al., "Harpagoside suppresses lipopolysaccharide-induced iNOS and COX-2 expression through inhibition of NF- $\kappa \mathrm{B}$ activation," Journal of Ethnopharmacology, vol. 104, no. 1-2, pp. 149-155, 2006.

[31] C.-S. Lai, J. H. Lee, C.-T. Ho et al., "Rosmanol potently inhibits lipopolysaccharide-induced iNOS and COX-2 expression through downregulating MAPK, NF- $\kappa \mathrm{B}, \mathrm{STAT} 3$ and $\mathrm{C} / \mathrm{EBP}$ signaling pathways," Journal of Agricultural and Food Chemistry, vol. 57, no. 22, pp. 10990-10998, 2009.

[32] S. Tang, X.-Y. Shen, H.-Q. Huang et al., "Cryptotanshinone suppressed inflammatory cytokines secretion in RAW264.7 macrophages through inhibition of the NF- $\kappa \mathrm{B}$ and MAPK signaling pathways," Inflammation, vol. 34, no. 2, pp. 111-118, 2011.

[33] A. S. Dhillon, S. Hagan, O. Rath, and W. Kolch, "MAP kinase signalling pathways in cancer," Oncogene, vol. 26, no. 22, pp. 3279-3290, 2007.

[34] T. Lawrence and C. Fong, "The resolution of inflammation: anti-inflammatory roles for NF- $\kappa \mathrm{B}$," The International Journal of Biochemistry and Cell Biology, vol. 42, no. 4, pp. 519-523, 2010.

[35] M. S. Hayden and S. Ghosh, "Shared principles in NF- $\kappa$ B signaling," Cell, vol. 132, no. 3, pp. 344-362, 2008.

[36] E. K. Kim and E.-J. Choi, "Pathological roles of MAPK signaling pathways in human diseases," Biochimica et Biophysica Acta, vol. 1802, no. 4, pp. 396-405, 2010. 


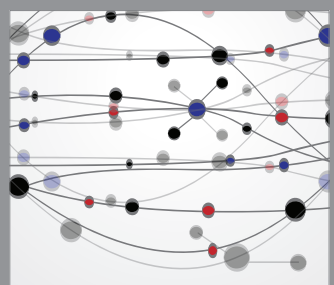

The Scientific World Journal
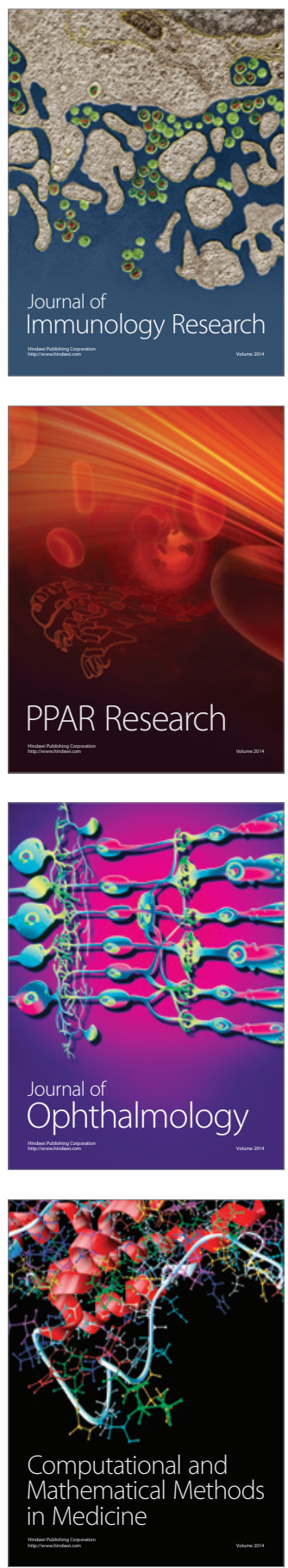

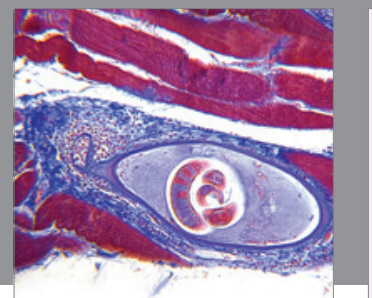

Gastroenterology

Research and Practice
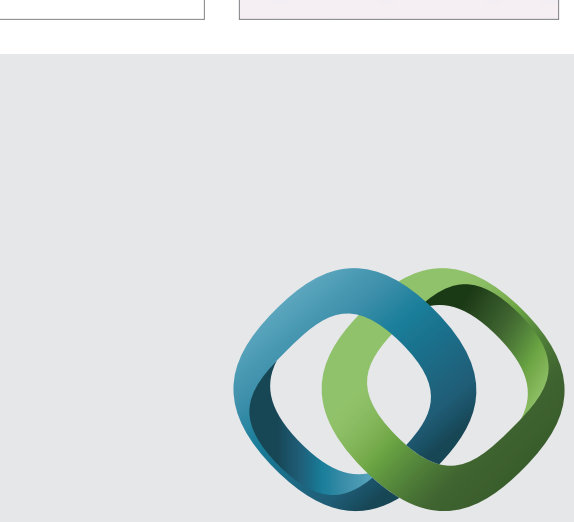

\section{Hindawi}

Submit your manuscripts at

http://www.hindawi.com
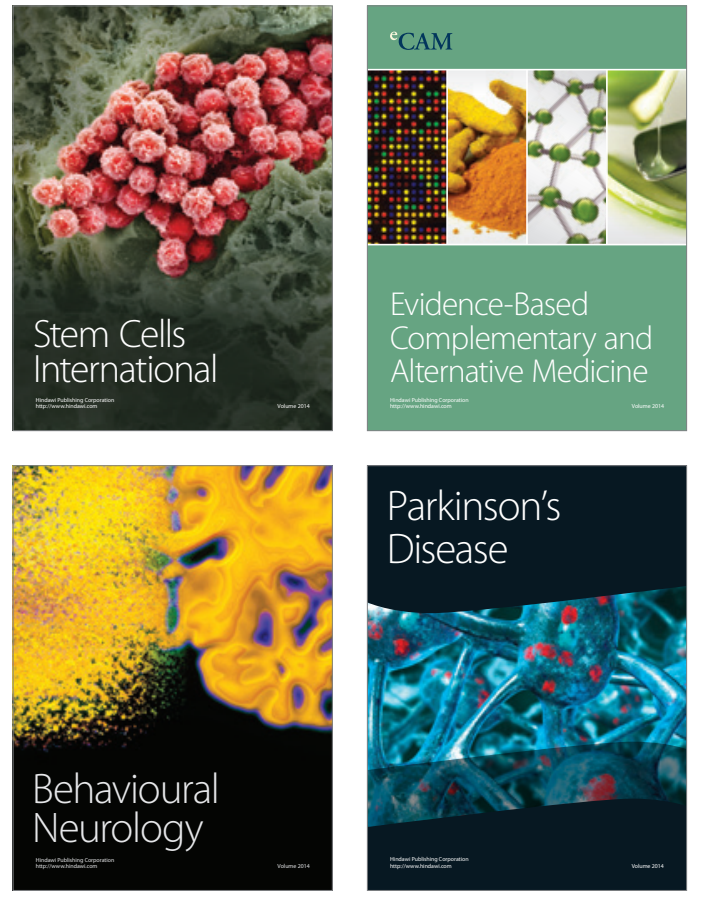
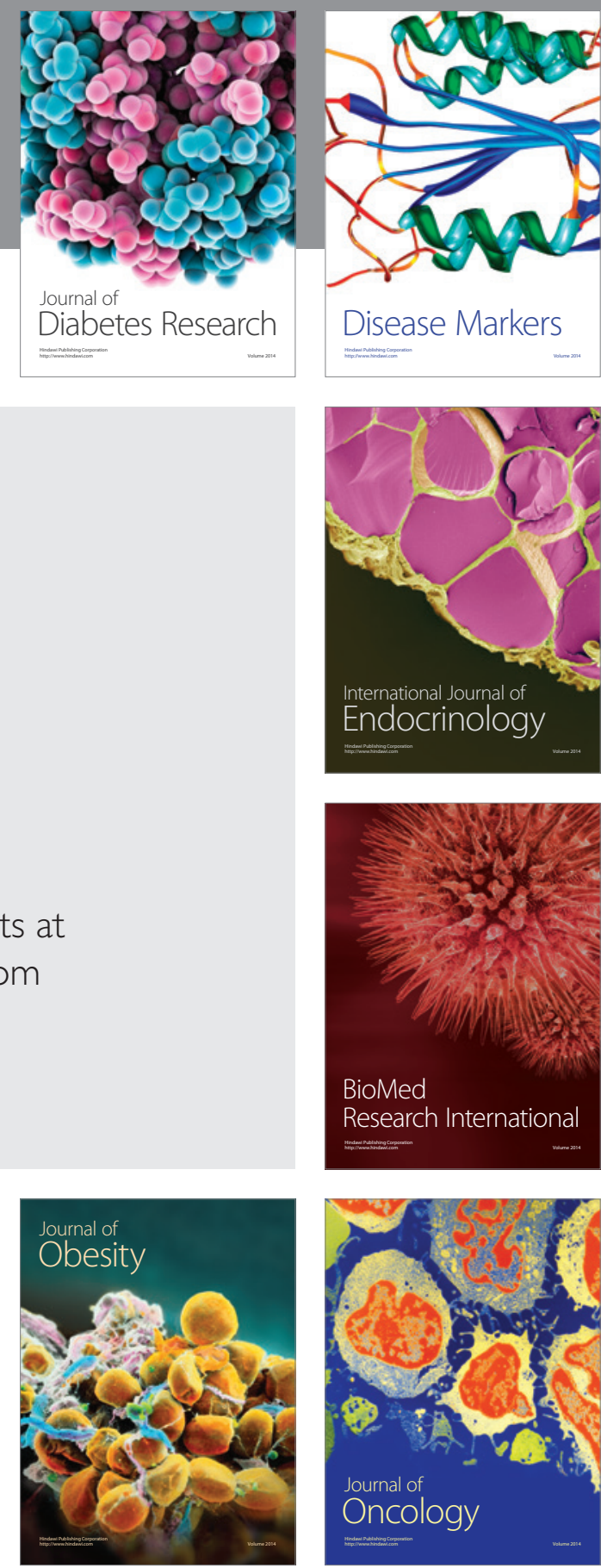

Disease Markers
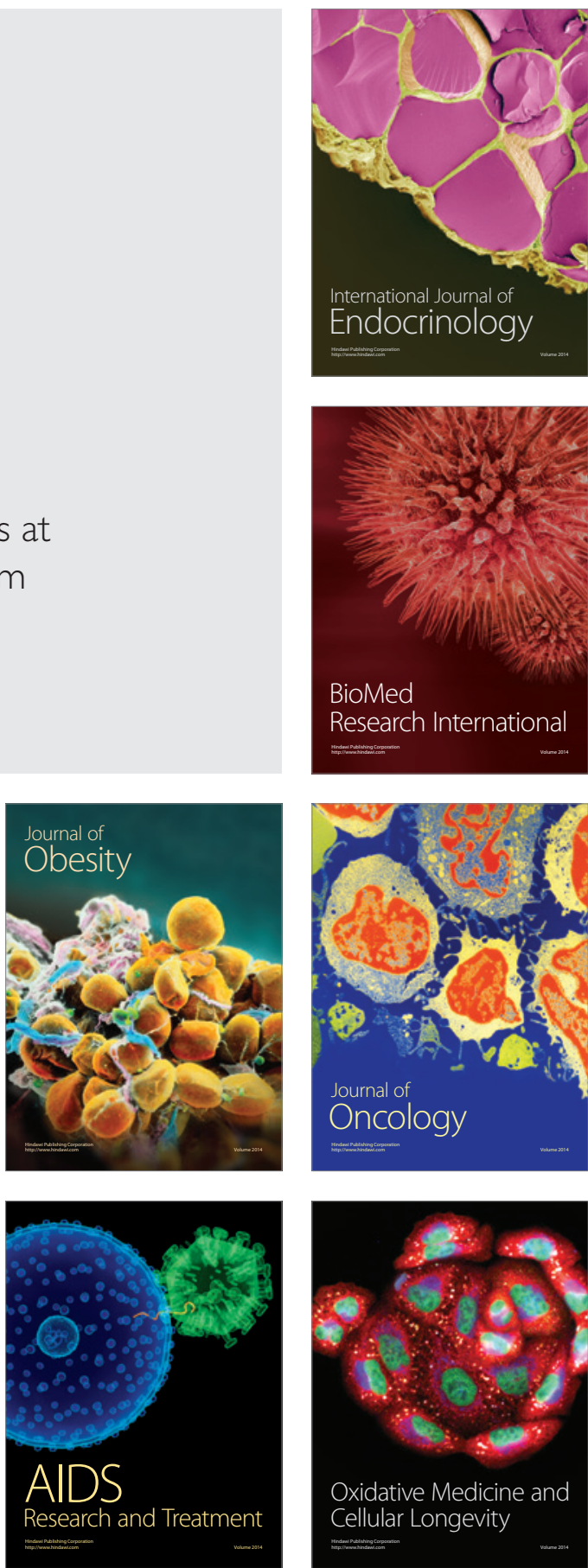